\title{
Determining the Amount of Rumen-Protected Methionine Supplement That Corresponds to the Optimal Levels of Methionine in Metabolizable Protein for Maximizing Milk Protein Production and Profit on Dairy Farms
}

\author{
J. Cho, ${ }^{\star}$ T. R. Overton,† C. G. Schwab, $¥$ and L. W. Tauer ${ }^{\star 1}$ \\ *Department of Applied Economics and Management, and \\ †Department of Animal Science, Cornell University, Ithaca, NY 14853 \\ $\ddagger$ Department of Animal and Nutritional Sciences, University of New Hampshire, Durham 03824
}

\begin{abstract}
The profitability of feeding rumen-protected Met (RPMet) sources to produce milk protein was estimated using a 2-step procedure: First, the effect of Met in metabolizable protein (MP) on milk protein production was estimated by using a quadratic Box-Cox functional form. Then, using these estimation results, the amounts of RPMet supplement that corresponded to the optimal levels of Met in MP for maximizing milk protein production and profit on dairy farms were determined. The data used in this study were modified from data used to determine the optimal level of Met in MP for lactating cows in the Nutrient Requirements of Dairy Cattle (NRC, 2001). The data used in this study differ from that in the NRC (2001) data in 2 ways. First, because dairy feed generally contains 1.80 to $1.90 \%$ Met in MP, this study adjusts the reference production value (RPV) from 2.06 to 1.80 or $1.90 \%$. Consequently, the milk protein production response is also modified to an RPV of 1.80 or $1.90 \%$ Met in MP. Second, because this study is especially interested in how much additional Met, beyond the 1.80 or $1.90 \%$ already contained in the basal diet, is required to maximize farm profits, the data used are limited to concentrations of Met in MP above 1.80 or $1.90 \%$. This allowed us to calculate any additional cost to farmers based solely on the price of an RPMet supplement and eliminated the need to estimate the dollar value of each gram of Met already contained in the basal diet. Results indicated that the optimal level of Met in MP for maximizing milk protein production was 2.40 and $2.42 \%$, where the RPV was 1.80 and $1.90 \%$, respectively. These optimal levels were almost identical to the recommended level of Met in MP of $2.40 \%$ in the NRC (2001). The amounts of RPMet re-
\end{abstract}

Received April 25, 2007.

Accepted June 11, 2007.

${ }^{1}$ Corresponding author: lwt1@cornell.edu quired to increase the percentage of Met in MP from each RPV to 2.40 and $2.42 \%$ were 21.6 and $18.5 \mathrm{~g} / \mathrm{d}$, respectively. On the other hand, the optimal levels of Met in MP for maximizing profit were 2.32 and 2.34\%, respectively. The amounts of RPMet required to increase the percentage of Met in MP from each RPV to 2.32 and $2.34 \%$ were 18.7 and $15.6 \mathrm{~g} / \mathrm{d}$, respectively. In each case, the additional daily profit per cow was estimated to be $\$ 0.38$ and $\$ 0.29$. These additional profit estimates were $\$ 0.02$ higher than the additional profit estimates for maximizing milk protein production.

Key words: methionine, milk protein, profit

\section{INTRODUCTION}

Dairy farmers in New York State (NYS) and most regions of the United States presently receive payment for their milk under the Federal Milk Marketing Order multiple-component pricing system. Payment is based on the quantities of milk components such as milk fat (butterfat), protein, and other solids. Of these components, milk protein is the most valuable for dairy farmers. Its price is the highest of all milk components, having significantly increased over the last 7 yr (Figure 1). This has led to great interest among dairy farmers in increasing milk protein production to increase profits.

There are several possible ways to increase milk protein production. These include genetic improvement (Gibson, 1989; McAllister et al., 1990; Hansen et al., 2002), switching breeds (Elbehri et al., 1994; Bailey et al., 2005), and modifying the diets of lactating dairy cows. Because genetic improvement of cows is a lengthy and difficult process for individual farmers, and switching breeds is expensive, increasing milk protein output through dietary means is the most practical short-term option. Of the various ways to do this, balancing AA in the dairy cows' diet is the most convenient way to enhance milk protein production because it can be accom- 


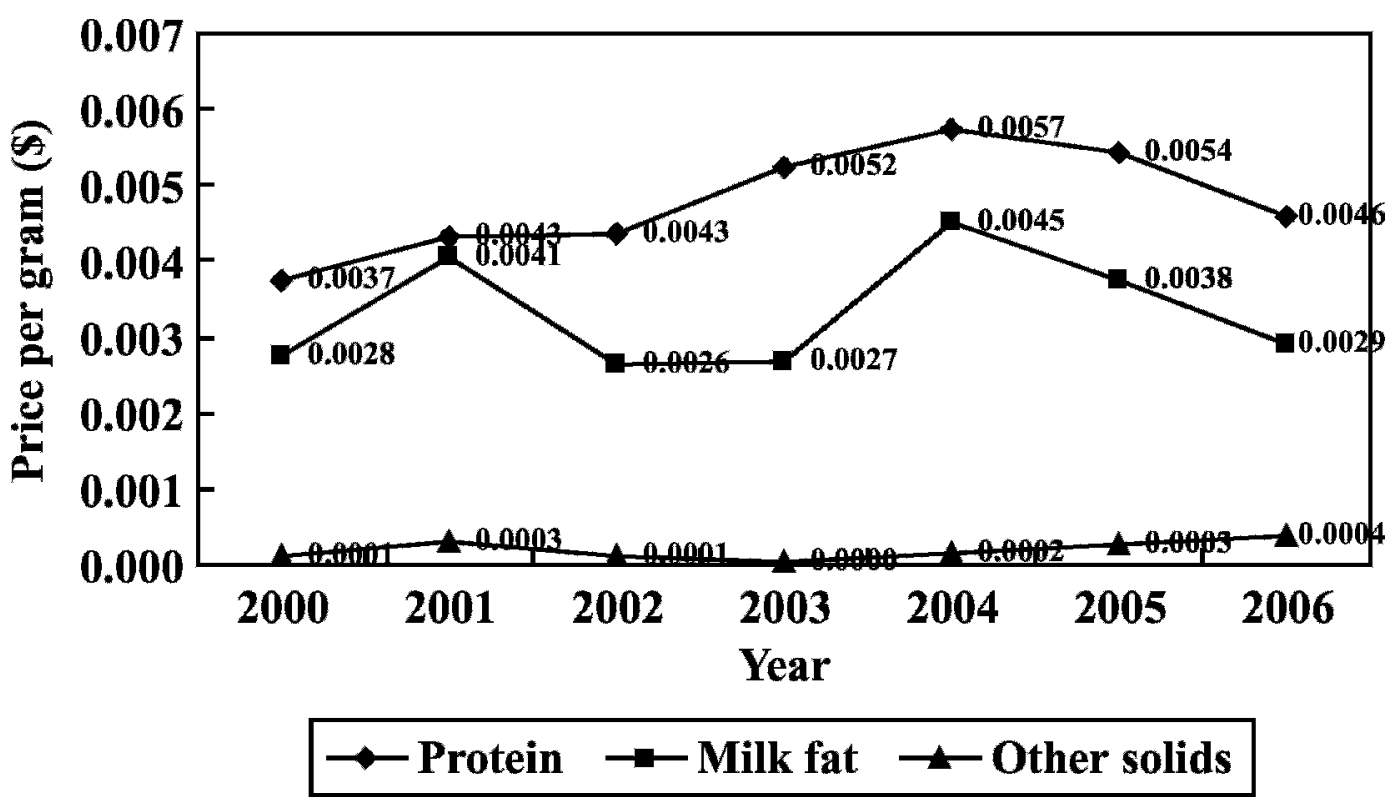

Figure 1. Average producer prices for milk components over the last 7 yr (2000-2006) based on the producer component price data provided by the Northeast Marketing Area of Agricultural Marketing Service, USDA.

plished simply by providing additional AA supplements to cows.

Of the essential AA in lactating dairy cows, Lys and Met are the 2 most limiting for the synthesis of milk and milk protein (Schwab et al., 1976), and these $2 \mathrm{AA}$ are often deficient in diets fed to lactating dairy cattle. Thus, several studies summarized in Nutrient Requirements of Dairy Cattle (NRC, 2001) have examined the relationship between postruminal supply of Lys or Met and milk protein production and found that increasing the postruminal supply of Lys or Met increases milk protein production (NRC, 2001). Although the different effect of Lys or Met on milk production reported in several studies depends on the differences in the status of Lys, Met, other AA, genetic traits, or the lactation status of the cows, many studies also reported that providing a dietary supplement of rumen-protected Lys (RPLys) or rumen-protected Met (RPMet) increases milk protein production (NRC, 2001; Misciattelli et al., 2003; Socha et al., 2005; Rulquin et al., 2006). This increase is mainly accomplished by increasing casein, the main ingredient in cheese (Donkin et al., 1989; Chow et al., 1990; Armentano et al., 1993). Thus, increasing milk protein production by adding an RPMet supplement to the diet of lactating cows is beneficial not only for dairy farmers, but also for cheese manufacturers.

According to the NRC (2001), the estimated optimal concentrations of Lys and Met in MP for the combined functions of maintenance and milk protein production are approximately 7.2 and $2.4 \%$, respectively. However, typical dairy lactating feed in NYS contains $>6.65 \%$ Lys and 1.8 to $1.9 \%$ Met, more than $92 \%$ of the Lys levels but only 75 to $79 \%$ of the Met levels recommended by the NRC (2001). Thus, dairy farmers may be able to increase milk protein production by adding an RPMet supplement to the diet of lactating cows. However, dairy farmers are reluctant to do this because there are presently no studies available on the economic benefits associated with providing this supplement. Therefore, this study examined the profitability of RPMet supplement on milk protein production using the following 2-step procedure: first, the effect of Met in MP on milk protein production was estimated using a quadratic Box-Cox functional form (QBC). Then, using these estimation results, the amounts of RPMet supplement that correspond to the optimal levels of Met in MP for maximizing milk protein production and profit on dairy farms were determined.

\section{MATERIALS AND METHODS}

\section{Quadratic Box-Cox Functional Form}

The choice of functional form is not a trivial task in applied economic data analysis. Although there are some popular forms, such as translog, quadratic, and Cobb-Douglas, which are frequently used in production analyses, there is no straightforward statistical test to determine which functional form is superior. Thus, in many cases, researchers choose a functional form ac- 
cording to their research purposes and statistical limitations imposed by their data.

Because this research entails a single-output and single-input production relationship, the Box-Cox transformation (Box and Cox, 1964) with a quadratic functional form is particularly useful to determine the most appropriate functional form. There are several reasons for this. First, the Box-Cox transformation requires no prior restrictions on estimating such a production relationship, so the estimated value of the transformation parameters describes the functional form that best fits the data. Second, this transformation results in less heteroscedastic residuals than those from the untransformed data (Box and Cox, 1964). Third, the QBC incorporates first-order and second-order effects of an input on output. Thus, the QBC has great flexibility. Finally, the QBC contains several traditional functions such as quadratic, translog, and inverse quadratic as special embedded parametric cases, and the validity of these functions can be tested by the likelihood ratio test. This reduces the effort in selecting the underlying functional form for a given set of data. Thus, this study utilized the following QBC to estimate the relationship between the percentage of milk protein and Met in MP.

The QBC used in this study can be expressed as

$$
y_{i}^{(\lambda)}=\beta_{0}+\beta_{1} x_{i}^{(\lambda)}+\beta_{2} x_{i}^{(\lambda)} x_{i}^{(\lambda)}+\varepsilon_{i}
$$

where the subscript $i$ indexes individual observation, $y_{i}$ is the milk protein content response (production response expressed as a percentage at each level of Met in MP relative to a reference production value); $x_{i}$ is the percentage of Met in MP; $\beta_{0}, \beta_{1}$, and $\beta_{2}$ are parameters to be estimated; $\lambda$ is the Box-Cox transformation parameter to be estimated; and $\varepsilon_{i}$ is the residual which is assumed to be normally distributed with zero mean and constant variance $\sigma^{2}$. The term $y_{i}^{(\lambda)}$ is the Box-Cox transformation $\left(y_{i}^{\lambda}-1\right) / \lambda$, and $x_{i}^{(\lambda)}$ is the Box-Cox transformation $\left(x_{i}^{\lambda}-1\right) / \lambda$, which are transformed with the common parameter $\lambda$ that can assume any value. Specifically, when the estimated value of $\lambda$ approaches 1 , equation [1] is reduced to the quadratic function; when $\lambda$ approaches zero, equation [1] is reduced to the translog function, and when $\lambda$ approaches -1 , equation [1] is reduced to the quadratic function with inverse specification.

In this study, the amount of feed consumed by each treatment group varied from experiment to experiment. Thus, if the selected dependent and independent variables in the QBC are those expressed on a quantity basis $(\mathrm{g} / \mathrm{d})$, the estimation result of the effect of Met in MP on milk production will be overestimated. Therefore, this study measured the response effect using vari- ables expressed as percentage of milk protein and the percentage of Met in MP, as was done in the NRC (2001). This specification minimizes the effects of other nutritional factors on milk protein production caused by the different level of feed consumption in each experiment.

The transformation parameter $\lambda$ in the $\mathrm{QBC}$ was estimated by the maximum likelihood estimation technique using the software STATA (Stata Corp., College Station, TX) because the $\mathrm{QBC}$ is nonlinear in its parameters. However, in the presence of heteroscedastic residuals, estimating the Box-Cox regression model can generate misleading results (Seaks and Layson, 1983; Blaylock and Smallwood, 1985). Due to the complexity of the maximum likelihood estimation technique for estimating the Box-Cox-type models, the majority of empirical analyses employing this estimation technique did not test significantly for heteroscedasticity, and the majority of statistical software programs do not provide any test for identifying such an econometric problem. Therefore, in this study, the QCB was re-estimated by the ordinary least squares estimator after modifying the data with the estimated parameter $\lambda$ to test heteroscedasticity by the Breusch-Pagan test.

If heteroscedasticity exists, the models should be modified as the QBC with a Just-Pope risk specification in a mean-variance framework (Just and Pope, 1978), or re-estimated by using alternative estimation techniques such as the Box-Cox with a weighted leastsquares correction for heteroscedasticity (Seaks and Layson, 1983). A Just-Pope specification would be especially useful because it allows formulating the heteroscedastic residuals as an inherent risk in the production function.

\section{Optimal RPMet Application}

When a single output and single input are measured on a quantity basis such as grams per day, and output is represented as a continuously differentiable function of input, the producer's strategy for maximizing profit is simply a matter of choosing the appropriate input level. If such a function is concave, the optimal level of input is determined to be the point at which the marginal product of input equals the ratio of a given input price and output price. However, this producer's strategy for maximizing profit described above cannot be directly applied to this study because the selected output and input in equation [1] are expressed as percentages. Therefore, this study used a different profit maximization method to determine the optimal application levels of RPMet supplement corresponding to the optimal levels of Met in MP for maximizing milk protein production and profit on dairy farms. 
The first derivative of the quadratic Box-Cox functional form is

$$
\begin{aligned}
& d y_{i} / d x_{i}=\lambda^{-(1 / \lambda)} x_{i}^{\lambda-1}\left(2 \beta_{2} x_{i}^{\lambda}-2 \beta_{2}+\beta_{1} \lambda\left[\beta_{2} x^{2 \cdot \lambda}\right.\right. \\
& \left.+x_{i}^{\lambda}\left(\beta_{1} \lambda-2 \beta_{2}\right)+\beta_{2}-\lambda\left(\beta_{1}-\beta_{0} \lambda-1\right)\right]^{(1-\lambda) / \lambda}
\end{aligned}
$$

In this study, this derivative represents the elasticity of protein production at a certain percentage of Met in MP $\left(x_{i}\right)$; that is, how much the percentage of milk protein increased or decreased when small changes were made in a certain percentage of Met in MP $\left(x_{i}\right)$. Thus, the optimal percentage of Met in MP for maximizing milk protein production is simply the point at which the output elasticity, the first derivative of the estimated $\mathrm{QBC}$, equals zero and begins to be negative.

The optimal level of Met in MP for maximizing profit is calculated according to the following steps. 1) Define the reference production value (RPV) of Met in $\operatorname{MP}\left(x_{0}\right)$ according to the general level of Met in MP in typical dairy lactating rations in NYS such as 1.80 or 1.90.2) Set the base production and input level corresponding to the RPV $\left(x_{0}\right)$ as the amount ( $\mathrm{g} / \mathrm{d}$ ) of base milk protein $\left(y_{x_{0}}\right)$ and the amount $(\mathrm{g} / \mathrm{d})$ of base Met $\left(\right.$ Met $\left._{x_{0}}\right)$. 3) Calculate the amount $(\mathrm{g} / \mathrm{d})$ of additional milk protein $\left(y_{x_{i}}\right)$ when the percentage of Met in MP changes from the RPV $\left(x_{0}\right)$ to a certain percentage of Met in MP $\left(x_{i}\right)$. To obtain the amount $(\mathrm{g} / \mathrm{d})$ of additional milk protein $\left(y_{x_{i}}\right)$, first rearrange the deterministic part of the QBC in equation [1], and multiply this by the amount $(\mathrm{g} / \mathrm{d})$ of base milk protein $\left(y_{x_{0}}\right)$ :

$$
\begin{gathered}
y_{x_{i}}=\left[\left\{\left(c+b\left(\left(x_{i}^{\lambda}-1\right) / \lambda\right)\right.\right.\right. \\
\left.\left.\left.+a\left(\left(x_{i}^{\lambda}-1\right) / \lambda\right)^{2}\right) \lambda+1\right\}\right]^{1 / \lambda} \times y_{x_{0}}
\end{gathered}
$$

4) Calculate the amount $(\mathrm{g} / \mathrm{d})$ of additional Met required $\left(\right.$ Met $\left._{x_{i}}\right)$ when the percentage of Met in MP changes from the RPV $\left(x_{0}\right)$ to a certain percentage of Met in MP $\left(x_{i}\right)$. Because the difference between a certain percentage of Met in MP $\left(x_{i}\right)$ and the RPV $\left(x_{0}\right)$ is $\left[x_{i}-\right.$ $x_{0}=\left\{\left(M_{x_{0}}+\operatorname{Met}_{x_{i}}\right) /\left(M P_{x_{0}}+\operatorname{Met}_{x_{i}}\right)-\left(\operatorname{Met}_{x_{0}} / M P_{x_{0}}\right)\right\} \times$ 100], the amount $(\mathrm{g} / \mathrm{d})$ of additional Met required $\left(M_{e} t_{x_{i}}\right)$ can be written as

$$
\begin{aligned}
\operatorname{Met}_{x_{i}}= & \left\{\left(x_{i}-x_{0}\right) M P_{x_{0}}^{2}\right\} /\left\{\left(x_{i}-x_{0}\right) M P_{x_{0}}\right. \\
& \left.+100\left(\operatorname{Met}_{x_{0}}-M P_{x_{0}}\right)\right\}
\end{aligned}
$$

where $M P_{x_{0}}=M e t_{x_{0}} / x_{0}$ is the amount (g/d) of total MP at the RPV $\left.\left(x_{0}\right) .5\right)$ Calculate the amount $(\mathrm{g} / \mathrm{d})$ of RPMet required $\left(R P M e t_{x_{i}}\right)$ when the percentage of Met in MP changes from the RPV $\left(x_{0}\right)$ to a certain percentage of Met in MP $\left(x_{i}\right)$ as

$$
\operatorname{RPMet}_{x_{i}}=\text { Met }_{x_{i}} / \text { TIAMet }
$$

where TIAMet is the total intestinal availability of an RPMet supplement, which is calculated as the ruminal escape rate multiplied by the intestinal digestibility of the RPMet supplement. 6) Calculate the additional (cumulative) daily revenue per cow $\left(R_{x_{i}}\right)$ when the percentage of Met in MP changes from the RPV $\left(x_{0}\right)$ to a certain percentage of Met in MP $\left(x_{i}\right)$ as

$$
R_{x_{i}}=y_{x_{i}} \times P_{\text {Prot }}
$$

where $P_{\text {Prot }}$ is a milk protein price per gram. 7) Calculate the additional (cumulative) daily cost per cow $\left(C_{x_{i}}\right)$ when the percentage of Met in MP changes from the RPV $\left(x_{0}\right)$ to a certain percentage of Met in $\operatorname{MP}\left(x_{i}\right)$ as

$$
C_{x_{i}}=R P M e t_{x_{i}} \times P_{M e t}
$$

where $P_{M e t}$ is a milk protein price per gram. 8) Calculate the additional (cumulative) daily profit per cow $\left(\pi_{x_{i}}\right)$ when the percentage of Met in MP changes from the $\mathrm{RPV}\left(x_{0}\right)$ to a certain percentage of Met in MP $\left(x_{i}\right)$ as

$$
\pi_{x_{i}}=R_{x_{i}}-C_{x_{i}}
$$

9) Determine the amount ( $\mathrm{g} / \mathrm{d}$ ) of RPMet required when the percentage of Met in MP changes from the RPV $\left(x_{0}\right)$ to the percentage of Met in MP where the calculated additional (cumulative) daily profit per cow is the maximum by incrementally changing the input using the spreadsheet software Excel (Microsoft, Redmond, WA).

\section{Data}

The data used in this study were modified from the database used to determine the optimal level of Met in MP for lactating cows in the NRC (2001). These data were collected from several existing studies and contain 28 experiments, conducted solely on Holsteins, with 87 treatments in which Met was infused continuously into the cow's abomasum or duodenum, or fed in rumenprotected form (Table 1). The data used in this study differed from that in the NRC (2001) in 2 ways. First, as NYS dairy feed generally contains 1.80 to $1.90 \%$ Met in MP, this study adjusted the RPV from 2.06 to 1.80 or $1.90 \%$. Consequently, the milk protein production response was also modified to an RPV of 1.80 or $1.90 \%$ Met in MP. Second, as this study was especially inter- 
Table 1. Studies used to determine the dose-response relationships for Lys and Met in $\mathrm{MP}^{1}$

\begin{tabular}{l} 
Reference \\
\hline Armentano et al. (1997) \\
Casper et al. (1987) \\
Casper and Schingoethe (1988) \\
Illg et al. (1987) \\
Munneke et al. (1991) \\
Papas et al. (1984a) \\
Papas et al. (1984b) \\
Pisulewski et al. (1996) \\
Polan et al. (1991) \\
Rogers et al. (1987) \\
Rulquin and Delaby (1997) \\
Rulquin and Delaby (1994) \\
Rulquin et al. (1994) \\
Schingoethe et al. (1988) \\
Schwab et al. (1976) \\
Schwab et al. (1992a) \\
Schwab et al. (1992b) \\
Socha (1994) \\
Socha et al. (1994a) \\
Socha et al. (1994b) \\
Yang et al. (1986)
\end{tabular}

${ }^{1}$ Source: NRC (2001).

ested in how much additional Met, beyond the 1.80 or $1.90 \%$ already contained in the basal diet, is required to maximize farm profits, the data used were limited to concentrations of Met in MP above 1.80\% (48 observations) or $1.90 \%$ ( 40 observations). Because the data used in the NRC (2001) contained observations that have a significantly lower level of Met in MP $(<1.85 \%)$ than RPV of 1.90 , these observations ( 8 observations) were deleted when estimating the QBC where RPV is $1.90 \%$. This allowed us to calculate any additional cost to farmers based solely on the price of an RPMet supplement, and eliminated the need to estimate the dollar value of each gram of Met already contained in the basal diet.

As in NRC (2001), this study also used only the restricted Met experiment data in which Lys was 6.50\% or more of MP to examine the production relationship between milk protein and Met in MP because low concentrations of Lys in MP limited milk protein responses to Met in MP. Total intestinal availability of Met (TIAMet), which is calculated as the ruminal escape rate multiplied by the intestinal digestibility of supplemental Met, was used to represent the contribution of supplemental Met to predicted flows of digestible Met originating from the basal diet. In NRC (2001), the TIAMet of infused Met was considered to be $100 \%$, and the TIAMet of all RPMet products was calculated to be $81 \%$ $(0.90 \times 0.90)$.

In this study, the final data set (containing 48 observations) in which the RPV was $1.80 \%$ showed an average $M e t_{x_{0}}$ was $41.55 \mathrm{~g} / \mathrm{d}$ per cow, an average $M t_{x_{0}}$ was $2,308.23 \mathrm{~g} / \mathrm{d}$, and an average $y_{0}$ was $1,052.25 \mathrm{~g} / \mathrm{d}$. On
Table 2. Estimation results for the quadratic Box-Cox functional form with the reference production value of $1.80 \%$ Met in $\mathrm{MP}^{1}$

\begin{tabular}{|c|c|c|c|c|}
\hline & \multicolumn{4}{|c|}{$\begin{array}{l}\text { Dependent variable: Milk protein } \\
\text { content responses }(\mathrm{g} / 100 \mathrm{~g})\end{array}$} \\
\hline & \multicolumn{4}{|c|}{$\begin{array}{l}\text { No. of observations }=48, \\
\operatorname{LR} \chi^{2}(2)=43.17, P>\chi^{2}=0\end{array}$} \\
\hline & Estimate & $\mathrm{SE}$ & z-value & $P>\mathrm{z}$ \\
\hline $\begin{array}{l}\text { Test } \mathrm{H}_{0} \\
\lambda=-1 \\
\lambda=0 \\
\lambda=1\end{array}$ & $\begin{array}{c}0.3451 \\
\text { Restricted } \\
\text { log likelihood } \\
-413.6801 \\
57.3194 \\
71.8203\end{array}$ & $\begin{array}{c}0.05 \\
\text { LR statistic } \\
\chi^{2} \\
1,038.67 \\
96.67 \\
67.67\end{array}$ & $\begin{array}{c}6.82 \\
P \text {-value } \\
\text { Prob }>\chi^{2} \\
0.00 \\
0.00 \\
0.00\end{array}$ & 0.00 \\
\hline \multirow{3}{*}{$\lambda=1$} & \multicolumn{4}{|c|}{$\begin{array}{l}\text { Dependent variable: Transformed milk protein } \\
\text { content responses }(\mathrm{g} / 100 \mathrm{~g})\end{array}$} \\
\hline & \multicolumn{4}{|c|}{$\begin{array}{c}\text { No. of observations }=48, P>F=0.00 \\
\mathrm{R}^{2}=0.59, \text { Adj. } \mathrm{R}^{2}=0.58\end{array}$} \\
\hline & Estimate & $\mathrm{SE}$ & $t$-value & $P>t$ \\
\hline $\begin{array}{l}\beta_{0} \\
\beta_{1} \\
\beta_{2}\end{array}$ & $\begin{array}{l}-9.0356 \\
14.8872 \\
-7.2902\end{array}$ & $\begin{array}{l}1.41 \\
3.23 \\
1.80\end{array}$ & $\begin{array}{r}-6.43 \\
4.61 \\
-4.06\end{array}$ & $\begin{array}{l}0.00 \\
0.00 \\
0.00\end{array}$ \\
\hline
\end{tabular}

the other hand, the final data set (containing 40 observations) in which the RPV was $1.90 \%$ showed an average $M e t_{x_{0}}$ was $43.27 \mathrm{~g} / \mathrm{d}$ per cow, an average $M P_{x_{0}}$ was $2,277.56 \mathrm{~g} / \mathrm{d}$, and an average $y_{0}$ was $1,047.46 \mathrm{~g} / \mathrm{d}$.

\section{RESULTS AND DISCUSSION}

Tables 2 and 3 report the estimated QBC (equation [1]) in which the RPV is 1.80 and $1.90 \%$, respectively. The values of the estimated parameters are different because the RPV and the number of observations in each model are different. After estimating both of the QBC by the ordinary least squares estimator with data modified by each estimated $\lambda$, this study tested heteroscedasticity by employing the Breusch-Pagan test. Because the null hypothesis (homoscedastic residual) of the Breusch-Pagan test was not rejected at the significance level of 0.05 , it was concluded that no heteroscedastic residuals were present in either of the QBC equations.

In this study, the RPMet price was assumed to be $\$ 0.0141 / \mathrm{g}$ (determined by taking the base price of a commercially available RPMet supplement that contained $85 \%$ of RPMet, sold to feed companies at $\$ 0.012 /$ $\mathrm{g}$ of RPMet, and adjusting for profit after being added to feed and resold to farmers); the TIAMet of an RPMet supplement was assumed to be $65.6 \%$ (this is the TIAMet of the same commercial RPMet supplement with an assumed price of $\$ 0.0141 / \mathrm{g}$ in this study); and the 
Table 3. Estimation results for the quadratic Box-Cox functional form with the reference production value of $1.90 \%$ Met in $\mathrm{MP}^{1}$

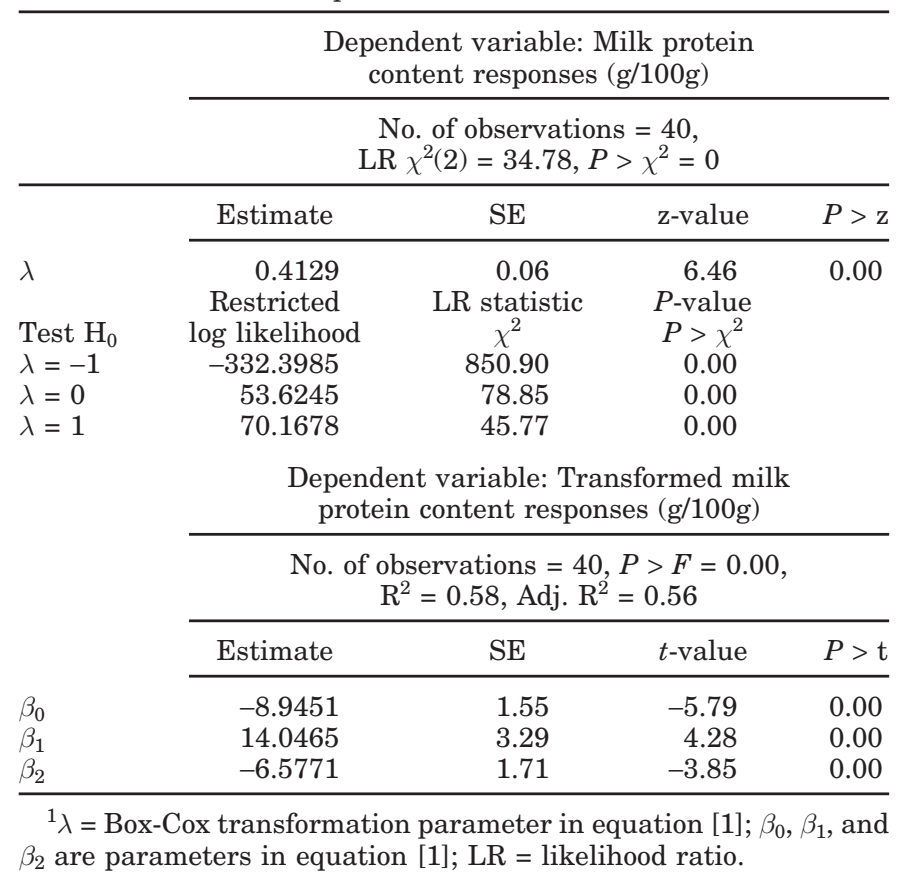

milk protein price was assumed to be $\$ 0.0046 / \mathrm{g}$, which was the average producer price for milk protein in 2006 . Based on these assumptions, the estimated output elasticity and additional profit at various levels of the percentage of Met in MP are reported in Figures 2 and 3. These estimation results indicate that the optimal levels of Met in MP for maximizing milk protein production were 2.40 and $2.42 \%$ (the optimal percentage of Met in MP for maximizing milk protein production is the point at which the output elasticity equals zero and begins to be negative), for RPV of 1.80 and $1.90 \%$, respectively. These optimal levels were almost identical to the recommended level of Met in MP of $2.40 \%$ in the NRC (2001). According to equation [5], the amounts of RPMet required to increase the percentage of Met in MP from each RPV to the 2.40 and $2.42 \%$ were 21.6 and $18.5 \mathrm{~g} /$ $\mathrm{d}$, respectively. On the other hand, the optimal level of Met in MP for maximizing profit was 2.32 and $2.34 \%$, respectively. Again, according to equation [5], the amounts of RPMet required to increase the percentage of Met in MP from each RPV to the 2.32 and $2.34 \%$ were 18.7 and $15.6 \mathrm{~g} / \mathrm{d}$, respectively. In each case, the additional daily profit per cow was estimated to be $\$ 0.38$ and $\$ 0.29$. These additional profit estimates were $\$ 0.02$

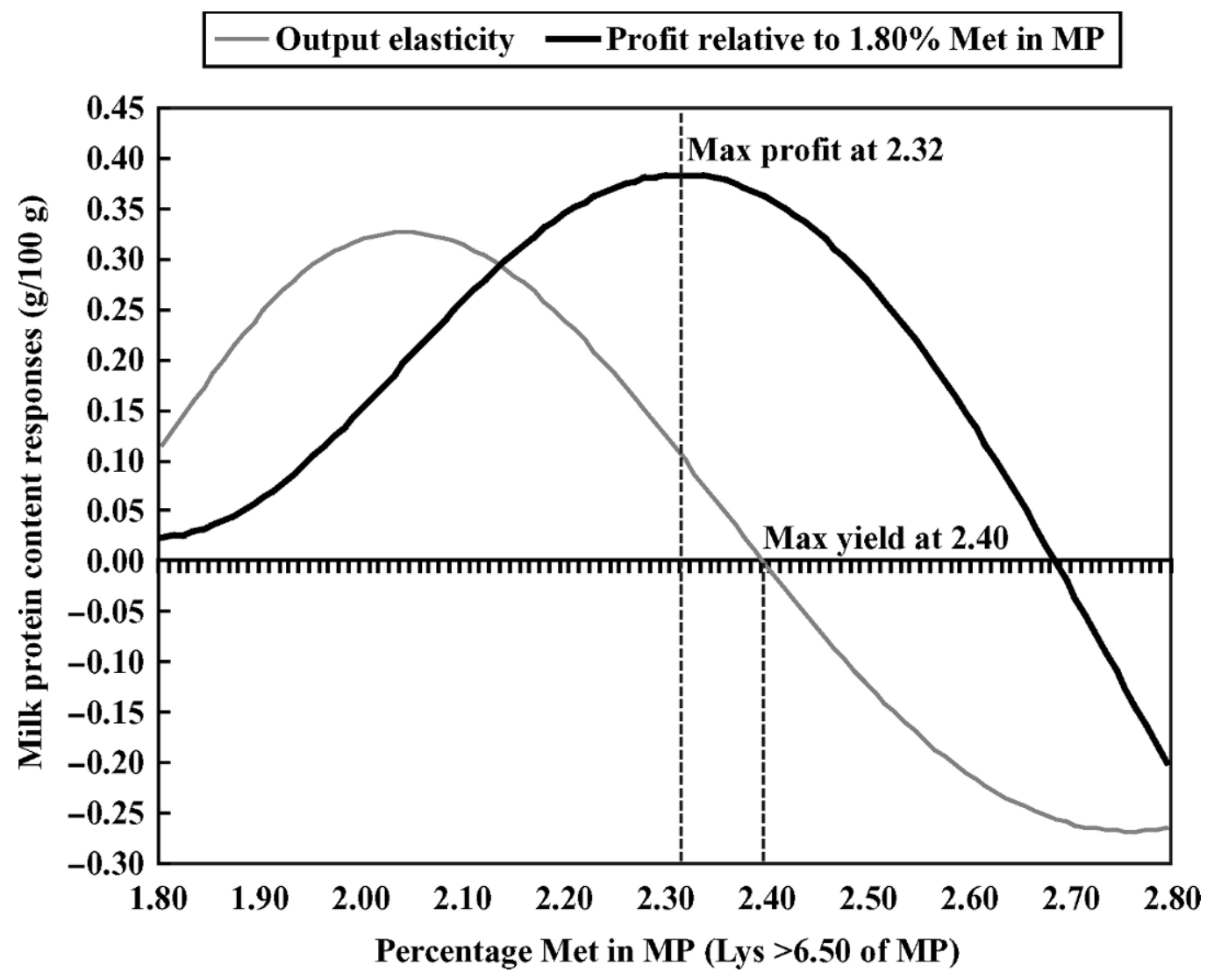

Figure 2. The estimated output elasticity and additional profit at various levels of the percentage of Met in MP where the reference production value of $1.80 \%$ Met in MP. 


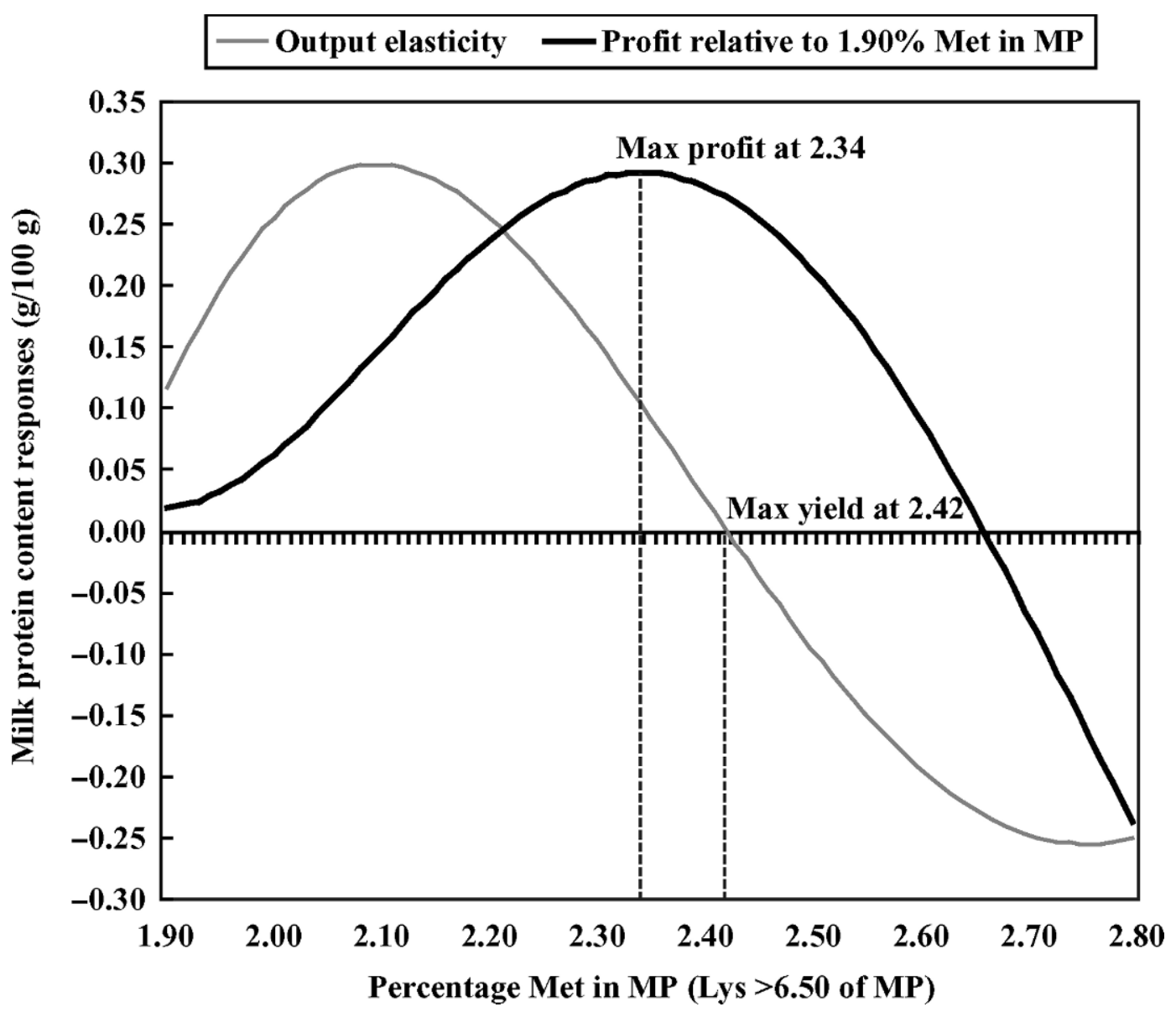

Figure 3. The estimated output elasticity and additional profit at various levels of the percentage of Met in MP where the reference production value of $1.90 \%$ Met in MP.

higher than the additional profit estimates for maximizing milk protein production. Over a 300-d lactation period, this would be $\$ 6.00 / \mathrm{cow}$; with a herd of 1,000 cows, this would amount to $\$ 6,000$ cost savings per year using economic optimal rather than output maximum use of Met in MP.

If any initial assumptions on the milk protein price, the RPMet price, or the TIAMet of an RPMet supplement are changed, the new optimal levels of Met in MP for maximizing milk protein production and profit, and the associated amounts of RPMet required to reach optimal levels of Met in MP, could be computed by inserting the new assumptions into the profit analysis formula provided in this study. This is because these initial assumptions do not affect the estimated parameters of the QBC in this study. For example, if we were to change the milk protein price of $\$ 0.0046 / \mathrm{g}$ in 2006 to $\$ 0.0037 / \mathrm{g}$ in 2000 ( $\$ 0.0037 / \mathrm{g}$ was the lowest average producer price for milk protein over the last $7 \mathrm{yr}$ ), the optimal level of Met in MP for maximizing milk protein production and the amounts of RPMet required to in- crease the percentage of Met in MP from each RPV to the optimal level of Met in MP for maximizing milk protein production would not be changed. This is because the milk protein price only affects the additional revenue formula (equation [6]) without affecting the estimated parameters of the QBC in this study. Thus, the optimal level of Met in MP for maximizing profit would be changed to 2.30 and $2.32 \%$, for RPV of 1.80 and $1.90 \%$, respectively. In this case, the amounts of RPMet required to increase the percentage of Met in MP from each RPV to the 2.30 and $2.32 \%$ would be 18.0 and $14.9 \mathrm{~g} / \mathrm{d}$, respectively. In each case, the additional daily profit per cow would be estimated to be $\$ 0.26$ and $\$ 0.19$. These additional profit estimates are $\$ 0.03$ and $\$ 0.02$ higher than the additional profit estimates for maximizing milk protein production. Similarly, if we changed the milk protein price of $\$ 0.0046 / \mathrm{g}$ in 2006 to $\$ 0.0057 / \mathrm{g}$ in 2004 ( $\$ 0.0057 / \mathrm{g}$ was the highest average producer price for milk protein over the last $7 \mathrm{yr}$ ), the optimal level of Met in MP for maximizing profit would be 2.33 and $2.36 \%$, respectively. The amounts of RPMet 
required to increase the percentage of Met in MP from each RPV to the 2.33 and $2.36 \%$ would be 19.1 and $16.4 \mathrm{~g} / \mathrm{d}$, respectively. In each case, the additional daily profit per cow was estimated to be $\$ 0.54$ and $\$ 0.42$. These additional profit estimates are $\$ 0.02$ higher than the additional profit estimates for maximizing milk protein production.

Although additional profit per cow is always higher for maximizing profit than that for maximizing milk production, the computed optimal levels of Met in MP for maximizing both protein production and profit are similar given the prices used for Met in MP and milk protein. Other prices will change the optimal profit input quantity, which may differ more significantly from the input quantity to maximize milk protein output. Therefore, in targeting the percentage of Met in MP and the amounts of RPMet application, farmers should focus on maximizing profit, not on maximizing milk protein production.

\section{ACKNOWLEDGMENT}

This research was supported by Cornell University Agricultural Experiment Station federal formula funds, Project No. 121-7410, Integrated Risk Management Strategies for Dairy Farmers, received from the Cooperative State Research, Education and Extension Service, USDA. Any opinions, findings, conclusions, or recommendations expressed in this publication are those of the authors and do not necessarily reflect the views of the USDA.

\section{REFERENCES}

Armentano, L. E., S. J. Bertics, and G. A. Ducharme. 1997. Response of lactating cows to methionine or methionine plus lysine added to high protein diets based on alfalfa and heated soybeans. J. Dairy Sci. 80:1194-1199.

Armentano, L. E., S. M. Swain, and G. A. Ducharme. 1993. Lactation response to ruminally protected methionine and lysine at two amounts of ruminally available nitrogen. J. Dairy Sci. 76:2963-2969.

Bailey, K. W., C. M. Jones, and A. J. Heinrichs. 2005. Economic returns to Holstein and Jersey herds under multiple component pricing. J. Dairy Sci. 88:2269-2280.

Blaylock, J. R., and D. M. Smallwood. 1985. Box-Cox transformations and a heteroscedastic error variance: Import demand equations revisited. Int. Stat. Rev. 53:91-97.

Box, G. E. P., and D. R. Cox. 1964. An analysis of transformations. J. R. Stat. Soc. Ser. B. Method. 26:211-243.

Casper, D. P., and D. J. Schingoethe. 1988. Protected methionine supplementation to a barley-based diet for cows during early lactation. J. Dairy Sci. 71:164-172.

Casper, D. P., D. J. Schingoethe, C.-M. J. Yang, and C. R. Mueller. 1987. Protected methionine supplementation with extruded blend of soybeans and soybean meal for dairy cows. J. Dairy Sci. 70:321-330.

Chow, J. M., E. J. DePeters, and R. L. Baldwin. 1990. Effect of rumenprotected methionine and lysine on casein in milk when diets high in fat or concentrate are fed. J. Dairy Sci. 73:1051-1061.

Donkin, S. S., G. A. Varga, T. F. Sweeney, and L. D. Muller. 1989. Rumen-protected methionine and lysine: Effects on animal per- formance, milk protein yield, and physiological measures. J. Dairy Sci. 72:1484-1491.

Elbehri, A., R. D. Yonkers, S. A. Ford, and S. I. Gripp. 1994. The relative profitability of Jersey versus Holstein farms under alternative milk pricing systems. J. Dairy Sci. 77:1296-1305.

Gibson, J. P. 1989. Altering milk composition through genetic selection. J. Dairy Sci. 72:2815-2825.

Hansen, M., M. S. Lund, M. K. Sørensen, and L. G. Christensen. 2002. Genetic parameters of dairy character, protein yield, clinical mastitis, and other diseases in Danish Holstein cattle. J. Dairy Sci. 85:445-452.

Illg, D. J., J. L. Sommerfeldt, and D. J. Schingoethe. 1987. Lactational and systemic responses to the supplementation of protected methionine in soybean meal diets. J. Dairy Sci. 70:620-629.

Just, R. E., and R. D. Pope. 1978. Stochastic specifications of production functions and economic implications. J. Econ. 7:67-86.

McAllister, A. J., J. A. Vesely, T. R. Batra, A. J. Lee, C. Y. Lin, G. L. Roy, J. M. Wauthy, K. A. Winter, and L. A. McClelland. 1990. Genetic changes in protein, milk and fat yields as a response to selection for protein yield in a closed population of Holsteins. J. Dairy Sci. 73:1593-1602.

Misciattelli, L., V. F. Kristensen, M. Vestergaard, M. R. Weisbjerg, K. Seirsen, and T. Hvelplund. 2003. Milk production, nutrient utilization and endocrine responses to increased postruminal lysine and methionine supply in dairy cows. J. Dairy Sci. 86:275-286.

Munneke, R. L., D. J. Schingoethe, and D. P. Casper. 1991. Lactational evaluation of ruminally protected methionine in diets containing extruded soybeans and urea. J. Dairy Sci. 74:227-233.

NRC. 2001. Nutrient Requirements of Dairy Cattle. 7th rev. ed. Natl. Acad. Sci., Washington, DC.

Papas, A. M., C. J. Sniffen, and T. V. Muscato. 1984a. Effectiveness of rumen protected methionine for delivering methionine post ruminally in dairy cows. J. Dairy Sci. 67:545-552.

Papas, A. M., J. L. Vicini, J. H. Clark, and S. Peirce-Sandner. 1984b. Effects of rumen- protected methionine on plasma free amino acids and production by dairy cows. J. Nutr. 114:2221-2227.

Pisulewski, P. M., H. Rulquin, J. L. Peyraud, and R. Verite. 1996. Lactational and systemic responses of dairy cows to post ruminal infusions of increasing amounts of methionine. J. Dairy Sci. 79:1781-1791.

Polan, C. E., K. A. Cummins, C. J. Sniffen, T. V. Muscato, J. L. Vicini, B. A. Crooker, J. H. Clark, D. G. Johnson, D. E. Otterby, B. Guillaume, L. D. Muller, G. A. Varga, R. A. Murray, and S. B. Peirce-Sandner. 1991. Responses of dairy cows to supplemental rumen-protected forms of methionine and lysine. J. Dairy Sci. 74:2997-3013.

Rogers, J. A., U. Krishnamoorthy, and C. J. Sniffen. 1987. Plasma amino acids and milk protein production by cows fed rumenprotected methionine and lysine. J. Dairy Sci. 70:789-798.

Rulquin, H., and L. Delaby. 1994. Lactational responses of dairy cows to graded amounts of rumen-protected methionine. J. Dairy Sci. 77(Suppl. 1):91. (Abstr.)

Rulquin, H., and L. Delaby. 1997. Effects of the energy balance of dairy cows on lactational responses to rumen-protected methionine. J. Dairy Sci. 80:2513-2522.

Rulquin, H., B. Graulet, L. Delaby, and J. C. Robert. 2006. Effect of different forms of methionine on lactational performance of dairy cows. J. Dairy Sci. 89:4387-4394.

Rulquin, H., C. Hurtaud, and L. Delaby. 1994. Effects of dietary protein level on lactational responses of dairy cows to rumenprotected methionine and lysine. Ann. Zootech. 43:245.

Schingoethe, D. J., D. P. Casper, C. Yang, D. J. Illg, J. L. Sommerfeldt, and C. R. Mueller. 1988. Lactational response to soybean meal, heated soybean meal, and extruded soybeans with ruminally protected methionine. J. Dairy Sci. 71:173-180.

Schwab, C. G., C. K. Bozak, N. L. Whitehouse, and M. M. A. Mesbah. 1992a. Amino acid limitation and flow to the duodenum at four stages of lactation. I. Sequence of lysine and methionine limitation. J. Dairy Sci. 75:3486-3502. 
Schwab, C. G., C. K. Bozak, N. L. Whitehouse, and V. M. Olson. 1992b. Amino acid limitation and flow to duodenum at four stages of lactation. 2. Extent of lysine limitation. J. Dairy Sci. 75:3503-3518.

Schwab, C. G., L. D. Saner, and A. B. Clay. 1976. Response of lactating dairy cows to abomasal infusion of amino acids. J. Dairy Sci. 59:1254-1270.

Seaks, T. G., and S. K. Layson. 1983. Box-Cox estimation with standard econometric problems. Rev. Econ. Stat. 65:160-164.

Socha, M. T. 1994. Determining the methionine requirements of lactating dairy cows. PhD Thesis. University of New Hampshire, Durham.

Socha, M. T., D. E. Putnam, B. D. Garthwaite, N. L. Whitehouse, N. A. Kierstead, C. G. Schwab, G. A. Ducharme, and J. C. Robert. 2005. Improving intestinal amino acid supply of pre- and postpar- tum dairy cows with rumen-protected methionine and lysine. J. Dairy Sci. 88:1113-1126.

Socha, M. T., C. G. Schwab, D. E. Putnam, N. A. Kierstead, N. L. Whitehouse, B. D. Garthwaite, and G. A. Ducharme. 1994a. Determining methionine requirements of dairy cows during midlactation by postruminally infusing incremental amounts of methionine. J. Dairy Sci. 77(Suppl. 1):93. (Abstr.)

Socha, M. T., C. G. Schwab, D. E. Putnam, N. L. Whitehouse, N. A. Kierstead, B. D. Garthwaite, and G. A. Ducharme. 1994b. Determining methionine requirements of dairy cows during early lactation by postruminally infusing incremental amounts of methionine. J. Dairy Sci. 77(Suppl. 1):65. (Abstr.)

Yang, C.-M. J., D. J. Schingoethe, and D. P. Casper. 1986. Protected methionine and heat- treated soybean meal for high producing dairy cows. J. Dairy Sci. 69:2348-2357. 